\title{
Proteomics of PTI and Two ETI Immune Reactions in Potato Leaves
}

\author{
Svante Resjö ${ }^{1,+}{ }^{,}$Muhammad Awais Zahid ${ }^{1,+}{ }^{+}$, Dharani Dhar Burra ${ }^{1}$, Marit Lenman ${ }^{1}$, \\ Fredrik Levander ${ }^{2}$ and Erik Andreasson $1, *$ (D) \\ 1 Department of Plant Protection Biology, Swedish University of Agricultural Sciences, 23053 Alnarp, Sweden; \\ svante.resjo@slu.se (S.R.); muhammad.awais.zahid@slu.se (M.A.Z.); Dharani.Burra@gmail.com (D.D.B.); \\ marit.lenman@slu.se (M.L.) \\ 2 Department of Immunotechnology, Lund University, 22100 Lund, Sweden; fredrik.levander@immun.lth.se \\ * Correspondence: Erik.Andreasson@slu.se; Tel.: +46-4041-5349 \\ + These authors contributed equally to this work.
}

Received: 3 July 2019; Accepted: 22 September 2019; Published: 24 September 2019

check for updates

\begin{abstract}
Plants have a variety of ways to defend themselves against pathogens. A commonly used model of the plant immune system is divided into a general response triggered by pathogen-associated molecular patterns (PAMPs), and a specific response triggered by effectors. The first type of response is known as PAMP triggered immunity (PTI), and the second is known as effector-triggered immunity (ETI). To obtain better insight into changes of protein abundance in immunity reactions, we performed a comparative proteomic analysis of a PTI and two different ETI models (relating to Phytophthora infestans) in potato. Several proteins showed higher abundance in all immune reactions, such as a protein annotated as sterol carrier protein 2 that could be interesting since Phytophthora species are sterol auxotrophs. RNA binding proteins also showed altered abundance in the different immune reactions. Furthermore, we identified some PTI-specific changes of protein abundance, such as for example, a glyoxysomal fatty acid beta-oxidation multifunctional protein and a MAR-binding protein. Interestingly, a lysine histone demethylase was decreased in PTI, and that prompted us to also analyze protein methylation in our datasets. The proteins upregulated explicitly in ETI included several catalases. Few proteins were regulated in only one of the ETI interactions. For example, histones were only downregulated in the ETI-Avr2 interaction, and a putative multiprotein bridging factor was only upregulated in the ETI-IpiO interaction. One example of a methylated protein that increased in the ETI interactions was a serine hydroxymethyltransferase.
\end{abstract}

Keywords: potato; immunity; proteomics; methylation; plants; ETI; PTI; solanum; late blight

\section{Introduction}

Plants can be attacked by many organisms, including oomycetes, fungi, and bacteria. They have therefore evolved sophisticated immune systems to protect themselves from invading pathogens, one example of which is the perception of pathogen-associated molecular patterns (PAMPs) via transmembrane pattern-recognition receptors (PRRs). PAMPs have been defined as highly conserved molecules with an important role in the fitness and survival of microbes [1]. Recognition of PAMPs results in activation of PAMP-triggered immunity (PTI), which initiates the induction of immune responses, like the production of reactive oxygen species (ROS), activation of mitogen-activated protein kinase (MAPK) cascades, and transcriptional induction of defense-related genes [2,3]. However, successful pathogens secrete effectors into the plant cell and thereby suppress PTI. This process is called effector-triggered susceptibility (ETS). To counteract this, some plants have also evolved resistance proteins ( $R$ proteins) that recognize effectors inside the cell, which results in the initiation 
of a second level of defense called effector-triggered immunity (ETI) [4]. ETI is associated with a strong immune response, such as programmed cell death at the site of infection, the hypersensitive response (HR), that reduces further spread of the pathogen [5].

PTI and ETI can involve similar defense responses, which include for example activation of kinases and defense gene induction. The difference between PTI and ETI is not clear, and these immune reactions can be considered as a continuum of signaling mechanisms [6]. For example, in a recent study, Leibman-Markus et al. [7] reported a nucleotide-binding leucine-rich repeat receptor (an $\mathrm{R}$ like protein), SINRC4a, to be directly associated with PRRs, which enhances PTI signaling in the absence of effectors.

Although many studies have investigated pathogen-induced changes in transcriptional patterns, there is a lack of information regarding proteomic changes during immune reactions, especially in major crop plants. Since genomic and transcriptomic studies provide no direct information on protein abundance, location, and post-transcriptional alterations, quantitative proteomic analyses are important for our understanding of cellular processes connected to plant defense responses. Protein methylation has only been described in plant immunity with regards to Arabidopsis thaliana histone $\mathrm{H} 3$, and in this study, a methyltransferase activity was necessary for fully functional immune reactions [8].

Potato late blight is one of the most devastating diseases in potatoes all over the world, and is caused by the oomycete Phytophthora infestans [9]. In order to combat late blight disease, there is a need for a detailed understanding of the defense responses to $P$. infestans, including how to combine resistance sources to achieve a sustainable solution. Two studied effectors of P. infestans, IpiO and Avr2, both induce HR formation upon recognition by their corresponding plant resistance proteins, the Blb1 and R2 family proteins, respectively [10-12]. Avr2 has been shown to associate with a putative phosphatase, BSU-like protein 1 (BSL1), and change brassinosteroid-associated signal transduction [13]. R2 perception of Avr2 is dependent on BSL1 [14]. Both these ETI reactions involve GTP binding and G-protein signaling, as was shown in our earlier proteomics study on one membrane-associated protein fraction [15]. From this proteomics data regarding downstream signaling before the onset of HR, we hypothesize that there are specific changes in protein abundance between different ETIs, similar to the difference between PTI and ETI.

This study aimed to achieve a better understanding of different plant immunity reactions by performing a quantitative proteomics analysis of PTI and two different ETIs (Blb1 and R2) in a protein fraction from a subsequent fractionation of the earlier studied potato immune proteins [15]. We used our established immunity-inducing and protein fractionation systems [15] to quantitatively analyze protein changes and methylation across these different immune reactions.

\section{Results and Discussion}

\subsection{General Characteristics of the Protein Dataset}

In this proteome analysis, 869 proteins were identified and quantified, 243 of which changed in abundance compared to control ( $p<0.01$, supplementary material 1, including GO terms) in at least one of the immune reactions (PTI, ETI-Avir2 or ETI-IpiO). Approximately a third of the quantified proteins displayed the same type of change in all three immune reactions (Figure 1). Another third changed in abundance in both ETI interactions, but not in PTI. The remaining proteins were distributed among the other combinations of conditions, as shown in Figure 1 and Tables 1-4. In the PTI interaction, we detected an increase in the abundance of 54 proteins, as well as a decrease of 53 . As for the ETI response, a total of 39 proteins showed an increased abundance in both ETI-Avr2 and ETI-IpiO interactions (Figure 1). Although protein abundance in the two ETI interactions overlapped, we were able to identify an increase in the abundance of 10 and 13 proteins, and a decrease in abundance of 16 and 24 proteins, that were specific to the ETI-IpiO and ETI-Avr2 respectively (Figure 1). Finally, we also analyzed protein methylation in our dataset, since we found a histone demethylase with decreased abundance in PTI, as well as several histones with decreased abundance in one of the ETI conditions. The overall overlap between the proteins identified in this study and in Burra et al. [15], 
which describes a different protein fraction of the same biological set up, is limited. In this study, we found 243 proteins that changed in abundance. In the previous study by Burra et al. [15], 183 proteins were found to change in abundance. The overlap between these two sets of proteins is only 22 proteins, indicating that indeed the different fractions contain different proteins.

A

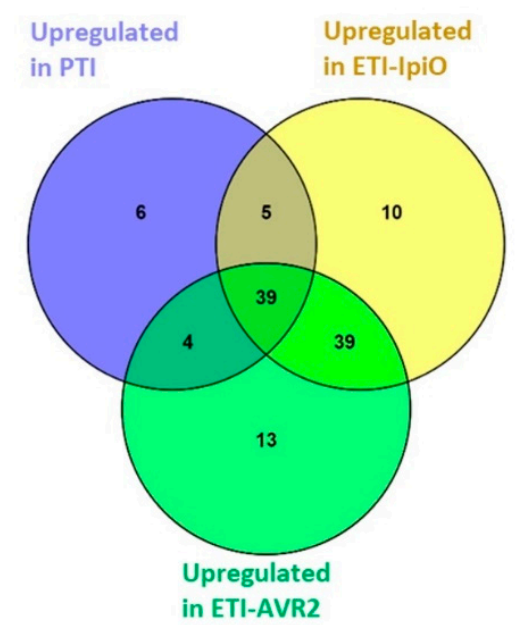

B

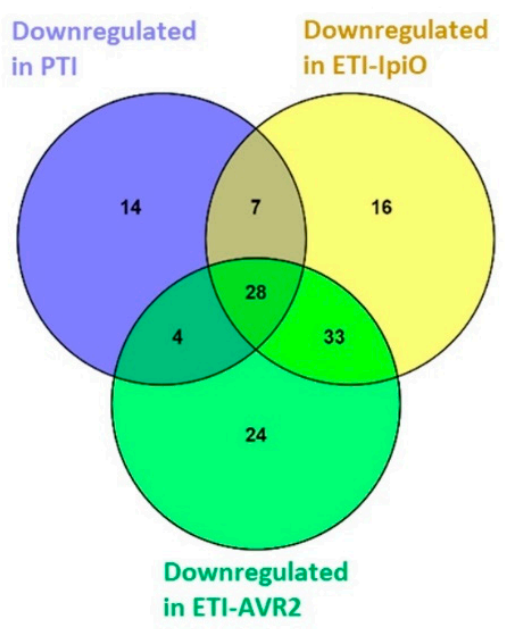

Figure 1. Diagram representing the results of the analysis with the respective number of proteins significantly changed in abundance in PAMP (pathogen-associated molecular patterns) triggered immunity (PTI) and effector-triggered immunity (ETI) interactions (Blb1-IpiO and AVR2-R2), on both (A) upregulated and (B) downregulated proteins.

\subsection{Proteins with Increased Abundance in the PTI Interaction}

Fifty-four proteins were found to be increased in the PTI response (Table 1). Proteins with a sequence similarity to a number of these have previously been shown to be important for PTI or to display an increase in abundance to PAMPs or other elicitors, which indicates that our system is a useful model of potato immune responses.

As one example, we identified a MAR-binding protein (PGSC0003DMP400010835) which was found to be increased in the PTI reaction, specifically. In tomatoes [16], a homologous protein was shown to be induced in response to COS-OGA elicitor treatment. Another protein that increased specifically in PTI and not in ETI interactions was annotated as DUF26 domain-containing protein 1 (PGSC0003DMP400063324). A previous report has shown that a DUF26 domain-containing protein, HvCRK1, is involved in regulating basal resistance but not R-gene dependent programmed cell death in barley [17]. In a recent study, the same protein was found to be increased in abundance when potato plants were challenged with intact $P$. infestans [18].

A metabolic protein that increased was Glyoxysomal fatty acid beta-oxidation multifunctional protein (PGSC0003DMP400008192). In previous studies, it has been shown that in Arabidopsis, a mutant lacking glyoxysomal fatty acid beta-oxidation resulted in a reduction of jasmonic acid (JA) accumulation [19], indicating that an increase of this protein might contribute to a generation of signaling molecules needed for the PTI response. Moreover, the identical protein was also found to be increased in abundance when potato leaves were inoculated with P. infestans [18]. Another protein that was upregulated in all three interactions was a germin (PGSC0003DMP400031837). Germin-like proteins (GLPs) belong to the functionally diverse cupin superfamily. There is substantial evidence of the involvement of germins and GLPs in general plant defense responses [20,21]. Additionally, transcripts and protein of a close homolog of this germin in Nicotiana benthamiana were also found to be increased in abundance after infiltration with disarmed Agrobacterium tumefaciens [22]. 
The protein annotated as UPF0497 (PGSC0003DMP400046973) was also found to increase. UPF0497 is a membrane protein commonly known as CASP (Casparian strip membrane domain proteins)-like protein, which is involved in cell wall strengthening [23]. A previous report has shown that UPF0497 has a higher transcript abundance when Castanea root is challenged with Phytophthora cinnamomi [24], which aligns our findings with previous studies and indicates its possible involvement in plant immunity.

Sterol carrier protein 2 (SCP-2) (PGSC0003DMP400014027) showed an increase in abundance, which is interesting since Phytophthora species are auxotrophs for sterols, as they lack the ability to produce oxidosqualene [25]. Therefore, it is tempting to speculate that the lower availability of sterols caused by the changed abundance of SCPs is part of immunity.

Moreover, we identified a protease inhibitor-related protein (C6F3B7) and a protease nucellin (PGSC0003DMP400025801) displaying increased abundance. Both protease inhibitors and proteases are known to be involved in PTI responses [26]. Furthermore, two DnaJ chaperone-related proteins (Q2XTC7 and Q6EIX7) were found to be present in higher abundance. The closest homolog to DnaJ-like protein (Q2XTC7) in N. benthamiana has earlier shown higher protein abundance upon agroinfiltration [22].

Table 1. Proteins with increased abundance from PTI and two ETI interactions, 18 hpi (hours post infiltration). A comparison was made between the immune-treated plants and the control plants infiltrated with medium only. All values are in $\log 2$ fold. Non-significant $p$ values are indicated by NA. All $p$-values $<0.01$ are shown in the table.

\begin{tabular}{|c|c|c|c|c|}
\hline \multirow{2}{*}{ Protein ID } & \multirow{2}{*}{ Protein Name } & \multicolumn{3}{|c|}{ Degree of Regulation ( $\log 2)$} \\
\hline & & PTI & ETI (Blb1-IpiO) & ETI (AVR2-R2) \\
\hline PGSC0003DMP400050772 & $\begin{array}{l}\text { Conserved gene of } \\
\text { unknown function }\end{array}$ & 4.57 & 5.07 & 4.63 \\
\hline P00296 & Plastocyanin & 4.47 & 5.10 & 4.88 \\
\hline Q8RXR5 & $\begin{array}{l}\text { Polyadenylate-binding } \\
\text { protein } 2\end{array}$ & 3.20 & 3.79 & 4.20 \\
\hline PGSC0003DMP400046973 & $\begin{array}{l}\text { UPF0497 membrane } \\
\text { protein }\end{array}$ & 3.17 & 3.13 & 3.41 \\
\hline Q2XTE0 & $\begin{array}{l}\text { Chlorophyll a-b binding } \\
\text { protein }\end{array}$ & 3.07 & 4.51 & 4.81 \\
\hline PGSC0003DMP400047776 & $\begin{array}{c}\text { Protein translocase secy } \\
\text { subunit }\end{array}$ & 2.97 & 2.80 & 3.01 \\
\hline PGSC0003DMP400022300 & $\begin{array}{l}\text { Chlorophyll binding } \\
\text { protein CP24 10B }\end{array}$ & 2.76 & 3.41 & 3.05 \\
\hline Q2XTC7 & DnaJ-like protein-like & 2.75 & 2.94 & 3.13 \\
\hline $\mathrm{P} 27489$ & $\begin{array}{l}\text { Chlorophyll } \mathrm{a}-\mathrm{b} \text { binding } \\
\text { protein } 13\end{array}$ & 2.57 & 4.21 & 4.37 \\
\hline PGSC0003DMP400011243 & Sodium/ exchanger & 2.56 & 2.85 & 2.65 \\
\hline Q2MI72 & $\begin{array}{l}\text { Photosystem II reaction } \\
\text { center protein }\end{array}$ & 2.45 & 3.30 & 3.18 \\
\hline Q0PWS7 & $\begin{array}{l}\text { Chlorophyll a-b binding } \\
\text { protein }\end{array}$ & 2.22 & 3.51 & 3.67 \\
\hline P10708 & $\begin{array}{l}\text { Chlorophyll a-b binding } \\
\text { protein } 7\end{array}$ & 2.17 & 3.28 & 3.32 \\
\hline C6F3B7 & $\begin{array}{c}\text { Protease } \\
\text { inhibitor-related protein }\end{array}$ & 2.08 & 2.46 & 1.83 \\
\hline P32764 & Rubisco small chain 3 & 2.04 & 2.16 & 2.33 \\
\hline P54260 & Aminomethyltransferase & 1.93 & 1.82 & 1.96 \\
\hline Q94KR9 & $\begin{array}{l}\text { Translation initiation } \\
\text { factor IF-1 }\end{array}$ & 1.77 & 1.77 & 1.86 \\
\hline Q9FFG6 & AT5g05480/MOP10_2 & 1.75 & 1.10 & 1.24 \\
\hline Q2MI49 & $\begin{array}{l}\text { Photosystem I } \\
\text { iron-sulfur center }\end{array}$ & 1.75 & 2.26 & 1.94 \\
\hline D2K7Z2 & $\begin{array}{l}\text { Photosystem I reaction } \\
\text { center subunit }\end{array}$ & 1.75 & 2.26 & 2.11 \\
\hline Q7YJ37 & $\begin{array}{l}\text { Cytochrome b559 } \\
\text { subunit alpha }\end{array}$ & 1.71 & 2.67 & 2.38 \\
\hline Q2MI71 & Cytochrome b6 & 1.67 & 1.93 & 1.85 \\
\hline PGSC0003DMP400017273 & Brg-1 associated factor & 1.66 & 2.11 & 2.25 \\
\hline E8ZG61 & Pectinesterase & 1.62 & 1.22 & 1.49 \\
\hline PGSC0003DMP400031837 & Germin & 1.57 & 1.43 & 1.36 \\
\hline
\end{tabular}


Table 1. Cont.

\begin{tabular}{|c|c|c|c|c|}
\hline \multirow{2}{*}{ Protein ID } & \multirow{2}{*}{ Protein Name } & \multicolumn{3}{|c|}{ Degree of Regulation $(\log 2)$} \\
\hline & & PTI & ETI (Blb1-IpiO) & ETI (AVR2-R2) \\
\hline PGSC0003DMP400033355 & $\begin{array}{l}\text { Mitochondrial import } \\
\text { inner membrane } \\
\text { translocase subunit Tim9 }\end{array}$ & 1.52 & 1.48 & 1.35 \\
\hline Q0PWS5 & $\begin{array}{l}\text { Chlorophyll a-b binding } \\
\text { protein }\end{array}$ & 1.48 & 1.80 & 1.52 \\
\hline PGSC0003DMP400030419 & $\begin{array}{l}\text { Heteronuclear } \\
\text { ribonucleoprotein A1 }\end{array}$ & 1.44 & 2.11 & 2.19 \\
\hline P12360 & $\begin{array}{l}\text { Chlorophyll a-b binding } \\
\text { protein } 6 \mathrm{~A}\end{array}$ & 1.43 & 1.76 & 1.58 \\
\hline PGSC0003DMP400034002 & Rubisco small chain 1 & 1.40 & 1.73 & 1.73 \\
\hline Q9SL05 & $\begin{array}{l}\text { Protein proton gradient } \\
\text { regulation } 5\end{array}$ & 1.36 & 1.69 & 1.31 \\
\hline P93014 & $30 \mathrm{~S}$ ribosomal protein $\mathrm{S} 5$ & 1.33 & 1.62 & 1.38 \\
\hline Q2VEI0 & $\begin{array}{c}\text { Photosystem II CP43 } \\
\text { protein }\end{array}$ & 1.29 & 1.74 & 1.82 \\
\hline Q2MI75 & $\begin{array}{l}\text { Photosystem II CP47 } \\
\text { protein }\end{array}$ & 1.24 & 1.80 & 1.93 \\
\hline PGSC0003DMP400053532 & 116 kD U5 small nuclear & 1.15 & 1.24 & 1.48 \\
\hline PGSC0003DMP400038531 & $\begin{array}{l}\text { Chloroplast photosystem } \\
\text { I, protein V }\end{array}$ & 1.04 & 1.95 & 1.88 \\
\hline PGSC0003DMP400014027 & Sterol carrier protein 2 & 0.99 & 1.19 & 1.54 \\
\hline Q2UVD9 & $\begin{array}{l}\text { PSII cytochrome b559 } \\
\text { 8kDa subunit }\end{array}$ & 0.89 & 1.51 & 1.58 \\
\hline Q2VEH0 & $\begin{array}{c}\text { ATP synthase subunit } \\
\text { beta }\end{array}$ & 0.51 & 0.88 & 1.10 \\
\hline Q6EIX7 & $\begin{array}{c}\text { Potyviral capsid } \\
\text { interacting protein } 2 b\end{array}$ & 2.14 & 1.57 & NA \\
\hline B3F8I0 & $\begin{array}{l}\text { Glyceraldehyde-3-phosphate } \\
\text { dehydrogenase }\end{array}$ & 1.56 & 1.48 & NA \\
\hline PGSC0003DMP400043522 & Peroxidase 12 & 1.37 & 1.02 & NA \\
\hline PGSC0003DMP400048828 & Splicing factor & 1.29 & 1.25 & NA \\
\hline PGSC0003DMP400039723 & $\begin{array}{l}\text { (S)-2-hydroxy-acid } \\
\text { oxidase }\end{array}$ & 1.14 & 0.96 & NA \\
\hline P93363 & Tyrosyl-tRNA synthetase & 1.73 & NA & 1.44 \\
\hline PGSC0003DMP400025801 & Nucellin & 1.48 & NA & 1.48 \\
\hline PGSC0003DMP400044750 & CXE carboxylesterase & 1.07 & NA & 0.87 \\
\hline Q0WVD8 & Adenylate translocator & 0.63 & NA & 0.52 \\
\hline E1AXT8 & Glycolate oxidase & 1.71 & NA & NA \\
\hline PGSC0003DMP400000661 & Beta-galactosidase & 1.42 & NA & NA \\
\hline PGSC0003DMP400010835 & $\begin{array}{l}\text { MAR-binding protein } \\
\text { DUF26 }\end{array}$ & 1.35 & NA & NA \\
\hline PGSC0003DMP400063324 & $\begin{array}{l}\text { domain-containing } \\
\text { protein } 1\end{array}$ & 1.33 & NA & NA \\
\hline Q8LK04 & $\begin{array}{l}\text { Glyceraldehyde-3-phosphate } \\
\text { dehydrogenase }\end{array}$ & 1.02 & NA & NA \\
\hline PGSC0003DMP400008192 & $\begin{array}{l}\text { Glyoxysomal fatty acid } \\
\text { beta-oxidation } \\
\text { multifunctional protein }\end{array}$ & 0.75 & NA & NA \\
\hline
\end{tabular}

\subsection{Proteins with Decreased Abundance in the PTI Interaction}

Fifty-three proteins were found to be decreased in our proteomics analysis of the PTI interaction (Table 2).

Interestingly, a lysine-specific histone demethylase (PGSC0003DMP400006728) was found to decrease in abundance in the PTI interaction. Lysine demethylases catalyze the demethylation of methylated histones, which in turn can change the degree of DNA condensation and consequently, gene activity [27]. The decreased abundance of histone demethylases in PTI might indicate that increased methylation of histones is a mechanism of immunity and prompted us to further investigate methylation in our dataset.

Two proteins annotated as leucine-rich repeat (LRR) family proteins (PGSC0003DMP400011041, PGSC0003DMP400002269) were found at lower abundance in PTI only. LRR domains are found in many different types of proteins, and these proteins are involved in a variety of biological processes, including R gene immunity [28,29]. LRR domains provide a structural framework for the formation of 
protein-protein interactions. However, R-proteins generally also contain a nucleotide-binding domain and an NBS domain, and these two potato LRR proteins do not.

The cell wall-related protein xyloglucan endotransglucosylase (Q9FZ05) was found to decrease in PTI and both ETI reactions. $\beta$-aminobutyric acid (BABA) is known to induce resistance in potatoes against $P$. infestans, and Q9FZ05 has been shown to decrease when potato leaves are treated with $10 \mathrm{mM}$ BABA [30]. This indicates that decreased levels of specific xyloglucan endotransglucosylases may be part of the defense against pathogens. Other cell wall-related proteins include pectinesterases (PMEs) that catalyze the removal of methyl groups from pectin, leading to loosening of the cell wall. PMEs make pectin more susceptible to microbial enzymes [31], and pectin esterification is correlated with resistance against Pectobacterium carotovorum in potato [32,33]. In the present study, pectinesterase (Q9LEB0) was shown to decrease in abundance during all three immune reactions.

Kunitz trypsin inhibitors are known to be involved in plant immunity, and to influence programmed cell death in A. thaliana [34]. In our study, a protein annotated as Kunitz-type protease inhibitor (PGSC0003DMP400016825) decreased in abundance in the PTI and ETI-Avr2 interactions. In a previous RNA study, a close homolog of this Kunitz-type protease inhibitor in N. benthamiana was also decreased in abundance upon infiltration with $A$. tumefaciens [22]. We also identified a protease, xylem serine proteinase 1 (PGSC0003DMP400012806) that decreased in abundance in PTI and both ETIs. We performed quantitative RT-PCR with primers directed to xylem serine proteinase 1 as a validation experiment for expression of this gene and confirmed that the transcript also decreased in abundance. The average fold change in expression in the PTI and ETI plants, as compared to control plants infiltrated with media, was 0.27 for PTI, 0.18 for ETI-IpiO, and 0.16 for ETI-Avr2, $p=0.015$. Furthermore, xylem serine proteinase 1 was found to decrease in abundance in a recent study by Xiao et al. [18], where they inoculated potatoes with P. infestans. A possible explanation of the decrease in abundance of Kunitz-type protease inhibitor and xylem serine proteinase 1 could be that they are part of fine-tuning the immunity or HR processes, which require some negative regulators [35].

Table 2. Proteins with decreased abundance from PTI and ETI interactions, 18 hpi (hours post infiltration). A comparison was made between the immune-treated plants and the control plants infiltrated with medium only. All values are in $\log 2$ fold. Non-significant $p$ values are indicated by NA. All $p$-values $<0.01$ are shown in the table.

\begin{tabular}{|c|c|c|c|c|}
\hline \multirow{2}{*}{ Protein ID } & \multirow{2}{*}{ Protein Name } & \multicolumn{3}{|c|}{ Degree of Regulation (log2) } \\
\hline & & PTI & ETI (Blb1-IpiO) & ETI (AVR2-R2) \\
\hline Q38JJ2 & $\begin{array}{l}\text { Disulfide-isomerase-like } \\
\text { protein }\end{array}$ & -0.59 & -1.02 & -0.71 \\
\hline Q5M9V4 & $\begin{array}{c}\text { ATP synthase subunit } \\
\text { alpha }\end{array}$ & -0.60 & -0.87 & -0.87 \\
\hline Q0WN54 & $\begin{array}{l}\text { Molecular chaperone } \\
\text { Hsp40/DnaJ }\end{array}$ & -0.64 & -0.82 & -0.79 \\
\hline Q9ZR78 & $\begin{array}{c}\text { ATP synthase subunit } \\
\text { beta }\end{array}$ & -0.66 & -0.91 & -0.87 \\
\hline PGSC0003DMP400042639 & $\begin{array}{l}\text { Conserved gene of } \\
\text { unknown function }\end{array}$ & -0.72 & -0.96 & -0.86 \\
\hline PGSC0003DMP400050963 & Chlorophyll a oxygenase & -0.76 & -0.77 & -0.78 \\
\hline PGSC0003DMP400053725 & $\begin{array}{c}\text { Ribonucleoprotein. } \\
\text { chloroplast }\end{array}$ & -0.78 & -1.05 & -0.77 \\
\hline PGSC0003DMP400053197 & $\begin{array}{c}\text { ATP synthase subunit } \\
\text { beta }\end{array}$ & -0.82 & -0.83 & -0.97 \\
\hline PGSC0003DMP400005664 & Elongation factor Ts & -0.84 & -1.61 & -1.24 \\
\hline PGSC0003DMP400010972 & $\begin{array}{l}\text { Hydroxypyruvate } \\
\text { reductase }\end{array}$ & -0.84 & -1.03 & -0.74 \\
\hline PGSC0003DMP400054045 & Alpha-1-fucosidase & -0.87 & -0.90 & -0.80 \\
\hline PGSC0003DMP400002234 & $30 \mathrm{~S}$ ribosomal protein $\mathrm{S} 1$ & -0.89 & -0.94 & -0.74 \\
\hline PGSC0003DMP400008070 & Ubiquitin-associated & -0.93 & -0.84 & -0.76 \\
\hline PGSC0003DMP400001305 & $\begin{array}{l}\text { Protein disulfide } \\
\text { isomerase family }\end{array}$ & -0.98 & -1.29 & -0.86 \\
\hline Q2XPV6 & Phosphoglycerate kinase & -1.04 & -0.94 & -0.75 \\
\hline A8MQR4 & $\begin{array}{c}60 S \text { acidic ribosomal } \\
\text { protein P0 }\end{array}$ & -1.05 & -1.10 & -0.74 \\
\hline Q9LEB0 & Pectinesterase & -1.05 & -1.04 & -1.08 \\
\hline
\end{tabular}


Table 2. Cont.

\begin{tabular}{|c|c|c|c|c|}
\hline \multirow{2}{*}{ Protein ID } & \multirow{2}{*}{ Protein Name } & \multicolumn{3}{|c|}{ Degree of Regulation $(\log 2)$} \\
\hline & & PTI & ETI (Blb1-IpiO) & ETI (AVR2-R2) \\
\hline Q40460 & $\begin{array}{l}\text { Ribulose bisphosphate } \\
\text { carboxylase }\end{array}$ & -1.05 & -1.39 & -1.41 \\
\hline PGSC0003DMP400031911 & $\begin{array}{l}\text { Pre-mRNA splicing } \\
\text { factor }\end{array}$ & -1.06 & -1.08 & -0.89 \\
\hline CosuW8 & $\begin{array}{l}\text { Eukaryotic translation } \\
\text { initiation factor }\end{array}$ & -1.07 & -0.77 & -0.92 \\
\hline PGSC0003DMP400027836 & Alpha-glucosidase & -1.08 & -1.28 & -1.33 \\
\hline PGSC0003DMP400014012 & Annexin & -1.19 & -1.25 & -1.21 \\
\hline PGSC0003DMP400012806 & $\begin{array}{c}\text { Xylem serine proteinase } \\
1\end{array}$ & -1.21 & -1.02 & -1.08 \\
\hline PGSC0003DMP400054512 & Cell division inhibitor & -1.29 & -1.00 & -0.95 \\
\hline PGSC0003DMP400019687 & $\begin{array}{l}\text { Translation initiation } \\
\text { factor IF-3 }\end{array}$ & -1.37 & -1.42 & -0.94 \\
\hline PGSC0003DMP400038185 & Transketolase & -1.52 & -1.10 & -0.77 \\
\hline Q9FZ05 & $\begin{array}{c}\text { Xyloglucan } \\
\text { endotransglucosylase }\end{array}$ & -1.71 & -0.86 & -1.18 \\
\hline Q84V30 & $\begin{array}{c}\text { Phosphatidylserine } \\
\text { decarboxylase } \\
\text { proenzyme } 1\end{array}$ & -2.00 & -1.58 & -1.80 \\
\hline O81394 & Phosphoglycerate kinase & -0.62 & -0.59 & NA \\
\hline Q6J995 & $\begin{array}{l}\text { Chloroplast glutamine } \\
\text { synthetase }\end{array}$ & -0.96 & -0.61 & NA \\
\hline PGSC0003DMP400001471 & Multicopper oxidase & -1.00 & -1.03 & NA \\
\hline F4JNJ2 & NAD(P)-binding protein & -1.05 & -0.72 & NA \\
\hline B0FPD8 & $\begin{array}{c}\text { Fructose-bisphosphate } \\
\text { aldolase }\end{array}$ & -1.16 & -0.89 & NA \\
\hline P93565 & $\begin{array}{l}\text { Fructose-bisphosphate } \\
\text { aldolase }\end{array}$ & -1.17 & -0.98 & NA \\
\hline Q5GM68 & $\begin{array}{l}\text { Phosphoenolpyruvate } \\
\text { carboxylase } 2\end{array}$ & -1.33 & -0.94 & NA \\
\hline F4J912 & Ribosomal protein L5 & -0.93 & NA & -0.73 \\
\hline Q41499 & Spliceosomal protein & -1.03 & NA & -0.53 \\
\hline PGSC0003DMP400048033 & Heme-binding protein & -1.14 & NA & -0.90 \\
\hline PGSC0003DMP400016825 & $\begin{array}{l}\text { Kunitz-type protease } \\
\text { inhibitor }\end{array}$ & -1.21 & NA & -1.20 \\
\hline PGSC0003DMP400002269 & $\begin{array}{l}\text { Leucine-rich repeat } \\
\text { protein }\end{array}$ & -0.62 & NA & NA \\
\hline Q2MIB4 & ATP synthase subunit b & -0.64 & NA & NA \\
\hline Q9SKI2 & Vacuolar protein & -0.69 & NA & NA \\
\hline PGSC0003DMP400052035 & $\begin{array}{l}\mathrm{KH} \text { domain-containing } \\
\text { protein }\end{array}$ & -0.72 & NA & NA \\
\hline PGSC0003DMP400032499 & Multicopper oxidase & -0.80 & NA & NA \\
\hline PGSC0003DMP400029544 & $\begin{array}{l}\text { Serine-threonine protein } \\
\text { kinase }\end{array}$ & -0.82 & NA & NA \\
\hline PGSC0003DMP400037531 & $\begin{array}{l}\text { Small nuclear } \\
\text { ribonucleoprotein }\end{array}$ & -0.87 & NA & NA \\
\hline Q38M62 & Uncharacterized protein & -0.87 & NA & NA \\
\hline PGSC0003DMP400036013 & $\begin{array}{l}\text { Nucleic acid binding } \\
\text { protein }\end{array}$ & -1.01 & NA & NA \\
\hline PGSC0003DMP400020414 & $\begin{array}{c}\text { Glyceraldehyde-3-phosphate } \\
\text { de }\end{array}$ & -1.13 & NA & NA \\
\hline PGSC0003DMP400011041 & $\begin{array}{l}\text { Leucine-rich repeat } \\
\text { family protein }\end{array}$ & -1.23 & NA & NA \\
\hline C0Z2D8 & AT1G20440 protein & -1.38 & NA & NA \\
\hline PGSC0003DMP400004729 & NMDA protein & -1.68 & NA & NA \\
\hline PGSC0003DMP400006728 & $\begin{array}{l}\text { Lysine-specific histone } \\
\text { demethylase }\end{array}$ & -2.00 & NA & NA \\
\hline
\end{tabular}

\subsection{Proteins with Increased Abundance in ETI Interactions}

Thirty-nine proteins increased in abundance in response to both ETI-Avr2 and ETI-IpiO interactions, but not in PTI (Figure 1, Table 3). Despite the significant overlap between proteins regulated by the two ETI interactions, we have identified 10 and 13 proteins that specifically increased in ETI-IpiO and ETI-Avr2, respectively (Figure 1). Among them, a putative multiprotein bridging factor (A0MWB6), with a DNA binding domain, was explicitly increased in the ETI-IpiO interaction. Similar proteins have been hypothesized to link ROS signaling, lipid metabolism, and pathogen defense [36]. In line with this, a family of catalase proteins (PGSC0003DMP400002845, Q6RFS8, and Q2PYW5) were found to increase 
in the ETI interactions. Catalase (CAT) is an iron porphyrin enzyme, which serves as a scavenger of reactive oxygen species (ROS) [37], and CAT related genes have been found to be regulated by biotic and abiotic stresses [38]. For example, the closest homolog in sugarcane, ScCAT2, was found to play a positive role in immune responses during plant-pathogen interactions [39]. The increase of CAT proteins, together with the putative multiprotein bridging factor, makes it tempting to speculate that ROS tolerance mechanisms are activated during ETI interaction. A protein involved in lipid transport, P-rich protein EIG-I30 (PGSC0003DMP400024366), was found to have increased abundance in ETI interactions. Previously, a closely related protein from the same family was shown to increase after BABA treatment of potato leaves [30]. The increase of P-rich protein EIG-I30 in the present study suggests its association with the defense-related response in ETI interactions of potato.

Our analysis of the proteins specifically increased in ETI interactions revealed the presence of proteins with RNA binding activity, such as mRNA binding protein (PGSC0003DMP400022826), heterogeneous nuclear ribonucleoprotein 27C (PGSC0003DMP400029964), and an ATP-dependent RNA helicase 8 (Q8RXK6). There is increasing evidence demonstrating a role for RNA-related proteins in regulating plant immunity [40]. Relating to the ATP-dependent RNA helicase 8 (Q8RXK6) that was specifically increased in ETI-Avr2, overexpression of the closest rice homolog OsBIRH1 in Arabidopsis resulted in plants with enhanced resistance against Alternaria brassicicola and Pseudomonas syringae pv. tomato DC3000 [41].

Another protein with increased abundance was carbonic anhydrase (Q5NE20). In a previous study, silencing of its closest homolog in N. benthamiana increased susceptibility to P. infestans [42]. Finally, heat shock protein 70 (PGSC0003DMP400015694) was found to increase in the ETI-Avr2 interaction. This type of protein has also been reported to interact with R-gene encoded proteins [43], which is in accordance with its increased abundance in the ETI interaction. Knowledge about these kinds of associations in major host plants such as potato is important since for example HSP70 is a large gene family and it is, therefore, challenging to know the exact target in new breeding and biotechnology.

Table 3. Proteins from two ETI interactions with increased abundance (ETI-IpiO and ETI-Avr2), 18 hpi (hours post infiltration). A comparison was made between the immune-treated plants and the control plants infiltrated with medium only. All values are in $\log 2$ fold. Non-significant $p$ values are indicated by NA. All $p$-values $<0.01$ are shown in the table.

\begin{tabular}{|c|c|c|c|}
\hline \multirow{2}{*}{ Protein ID } & \multirow{2}{*}{ Protein Name } & \multicolumn{2}{|c|}{ Degree of Regulation ( $\log 2)$} \\
\hline & & ETI (Blb1-IpiO) & ETI (AVR2-R2) \\
\hline PGSC0003DMP400024366 & P-rich protein EIG-I30 & 4.45 & 5.3 \\
\hline PGSC0003DMP400015464 & $\begin{array}{c}\text { Chlorophyll a/b binding } \\
\text { protein }\end{array}$ & 6.24 & 5.03 \\
\hline PGSC0003DMP400007091 & Acetylglutamate kinase & 2.8 & 3.76 \\
\hline Q40430 & PSI-H & 3.07 & 3.35 \\
\hline Q7M1K8 & $\begin{array}{l}\text { Chlorophyll a-b binding } \\
\text { protein }\end{array}$ & 3.01 & 3.18 \\
\hline PGSC0003DMP400029632 & ATP synthase delta chain & 2.49 & 2.69 \\
\hline PGSC0003DMP400002845 & Catalase isozyme 2 & 1.95 & 2.21 \\
\hline P06183 & $\begin{array}{l}\text { Photosystem II } 10 \mathrm{kDa} \\
\text { polypeptide }\end{array}$ & 2.16 & 2.2 \\
\hline Q9SR73 & 40 S ribosomal protein S28-1 & 2.14 & 2.16 \\
\hline P14278 & $\begin{array}{l}\text { Chlorophyll a-b binding } \\
\text { protein } 4\end{array}$ & 2.06 & 2.14 \\
\hline Q9S7N7 & $\begin{array}{c}\text { PS I reaction center subunit } \\
\text { V }\end{array}$ & 2.19 & 2.12 \\
\hline Q3S492 & Proteinase inhibitor I & 1.97 & 1.8 \\
\hline Q2MIA5 & Photosystem II D2 protein & 1.75 & 1.78 \\
\hline PGSC0003DMP400022826 & MRNA binding protein & 1.62 & 1.54 \\
\hline PGSC0003DMP400013603 & $\begin{array}{l}\text { Translation initiation factor } \\
\text { IF-1 }\end{array}$ & 1.25 & 1.51 \\
\hline Q70PN9 & Putative PSI-D subunit & 1.49 & 1.42 \\
\hline PGSC0003DMP400034978 & $\begin{array}{l}\text { PS I reaction center subunit } \\
\text { IV isoform }\end{array}$ & 1.36 & 1.34 \\
\hline
\end{tabular}


Table 3. Cont.

\begin{tabular}{|c|c|c|c|}
\hline \multirow{2}{*}{ Protein ID } & \multirow{2}{*}{ Protein Name } & \multicolumn{2}{|c|}{ Degree of Regulation $(\log 2)$} \\
\hline & & ETI (Blb1-IpiO) & ETI (AVR2-R2) \\
\hline B8XLF1 & $\begin{array}{l}\text { Chlorophyll a-b binding } \\
\text { protein }\end{array}$ & 1.82 & 1.32 \\
\hline PGSC0003DMP400030353 & $\begin{array}{c}\text { Cytosolic } \\
\text { acetoacetyl-coenzyme A } \\
\text { thiolase }\end{array}$ & 1.26 & 1.28 \\
\hline F1KC21 & Photosystem II protein D1 & 1.16 & 1.23 \\
\hline PGSC0003DMP400012170 & ATP synthase subunit $\mathrm{O}$ & 1.16 & 1.21 \\
\hline PGSC0003DMP400030249 & Chloroplast protease & 0.99 & 1.2 \\
\hline PGSC0003DMP400048099 & Glycolate oxidase & 1.03 & 1.19 \\
\hline PGSC0003DMP400031997 & $\begin{array}{l}\text { Photosystem II } 11 \mathrm{kDa} \\
\text { protein }\end{array}$ & 1.04 & 1.19 \\
\hline P25079 & $\begin{array}{l}\text { Ribulose bisphosphate } \\
\text { carboxylase large chain }\end{array}$ & 0.95 & 1.13 \\
\hline PGSC0003DMP400030421 & $\begin{array}{l}\text { Heterogeneous nuclear } \\
\text { ribonucleoprotein A1 }\end{array}$ & 1.37 & 1.11 \\
\hline PGSC0003DMP400025599 & $\begin{array}{l}\text { Conserved gene of unknown } \\
\text { function }\end{array}$ & 0.95 & 1.05 \\
\hline Q2MIA8 & $\begin{array}{l}\text { DNA-directed RNA } \\
\text { polymerase beta }\end{array}$ & 0.99 & 0.98 \\
\hline Q69GY7 & $\begin{array}{c}\text { Cytochrome b6-f iron-sulfur } \\
\text { subunit }\end{array}$ & 0.97 & 0.92 \\
\hline PGSC0003DMP400052418 & $\begin{array}{c}\text { Gamma-glutamyl } \\
\text { transferase }\end{array}$ & 1.15 & 0.9 \\
\hline PGSC0003DMP400017746 & $\begin{array}{l}\text { Oxygen-evolving enhancer } \\
\text { protein } 1\end{array}$ & 0.97 & 0.89 \\
\hline Q9S841 & $\begin{array}{l}\text { Oxygen-evolving enhancer } \\
\text { protein } 1-2\end{array}$ & 0.96 & 0.88 \\
\hline PGSC0003DMP400029964 & $\begin{array}{l}\text { Heterogeneous nuclear } \\
\text { ribonucleoprotein } 27 \mathrm{C}\end{array}$ & 0.61 & 0.79 \\
\hline P50433 & $\begin{array}{c}\text { Serine } \\
\text { hydroxymethyltransferase }\end{array}$ & 0.62 & 0.74 \\
\hline P93566 & $\begin{array}{l}\text { Oxygen-evolving enhancer } \\
\text { protein } 2\end{array}$ & 0.85 & 0.73 \\
\hline PGSC0003DMP400021624 & PRPL11 & 0.87 & 0.72 \\
\hline Q00321 & $\begin{array}{l}\text { Chlorophyll a-b binding } \\
\text { protein }\end{array}$ & 0.83 & 0.72 \\
\hline PGSC0003DMP400046718 & NAD dependent epimerase & 0.75 & 0.58 \\
\hline Q2MI64 & 50 S ribosomal protein L14 & 0.82 & 0.58 \\
\hline Q38HV4 & $\begin{array}{l}\text { Fructose-bisphosphate } \\
\text { aldolase }\end{array}$ & 1.91 & NA \\
\hline PGSC0003DMP400038572 & $\begin{array}{c}\text { Fructose-bisphosphate } \\
\text { aldolase }\end{array}$ & 1.69 & NA \\
\hline PGSC0003DMP400003396 & $\begin{array}{l}\text { Non-specific lipid-transfer } \\
\text { protein } 1\end{array}$ & 1.57 & NA \\
\hline C9EFD1 & $\begin{array}{l}\text { Chloroplast ribosomal } \\
\text { protein }\end{array}$ & 1.24 & NA \\
\hline A0MWB6 & $\begin{array}{l}\text { Transcriptional coactivator } \\
\text { multiprotein bridging factor }\end{array}$ & 1.09 & NA \\
\hline PGSC0003DMP400041249 & EMB2394 & 0.95 & NA \\
\hline PGSC0003DMP400025698 & High mobility group protein & 0.87 & NA \\
\hline P26320 & $\begin{array}{l}\text { Oxygen-evolving enhancer } \\
\text { protein } 1\end{array}$ & 0.78 & NA \\
\hline PGSC0003DMP400007506 & Photosystem Q & 0.7 & NA \\
\hline C5MR70 & $\begin{array}{l}\text { Chloroplast manganese } \\
\text { stabilizing protein-II }\end{array}$ & 0.45 & NA \\
\hline B0ZTE3 & Starch synthase & NA & 4.41 \\
\hline PGSC0003DMP400037406 & $21 \mathrm{kD}$ protein & NA & 1.90 \\
\hline PGSC0003DMP400015440 & Ferritin & NA & 1.90 \\
\hline Q6RFS8 & Catalase & NA & 1.42 \\
\hline PGSC0003DMP400048120 & Photosystem I subunit XI & NA & 1.38 \\
\hline Q5NE20 & Carbonic anhydrase & NA & 1.36 \\
\hline P26575 & Rubisco small chain $2 \mathrm{~A}$ & NA & 1.31 \\
\hline
\end{tabular}


Table 3. Cont.

\begin{tabular}{cccc}
\hline \multirow{2}{*}{ Protein ID } & Protein Name & \multicolumn{2}{c}{ Degree of Regulation (log2) } \\
\cline { 3 - 4 } & & ETI (Blb1-IpiO) & ETI (AVR2-R2) \\
\hline Q308A9 & Ferritin & NA & 1.28 \\
PGSC0003DMP400015694 & Heat shock protein 70 & NA & 1.20 \\
Q8RXK6 & DEAD-box RNA helicase 8 & NA & 1.11 \\
PGSC0003DMP400006368 & Ferredoxin-NADP reductase & NA & 1.10 \\
Q2PYW5 & Catalase & NA & 0.99 \\
PGSC0003DMP400025425 & Gene of unknown function & NA & 0.75 \\
\hline
\end{tabular}

\subsection{Proteins with Decreased Abundance in the ETI Interaction}

Seventy-three proteins decreased in at least one of the ETI conditions, but not in PTI (Table 4). An endoglucanase (Q42871) displayed decreased abundance in both ETI interactions. Its closest homolog in tomatoes, Cel1, has been found to decrease upon fungal infection, indicating a possible role in plant-pathogen interactions in solanum [44]. In another study, Flors et al. [45] found that when the endo-beta-1,4-glucanases Cel1 and Cel2 were lacking, susceptibility to Botrytis cinerea in tomatoes was decreased. Both of these findings indicate that decreased abundance of the Q42871 endoglucanase can be part of a successful immune response in potatoes.

The metabolic enzyme ferredoxin-dependent glutamate synthase 1 (PGSC0003DMP400017124) displayed decreased abundance in ETI. As a validation experiment for this gene, quantitative RT-PCR with primers directed to ferredoxin-dependent glutamate synthase 1 also revealed decreased transcript levels. The average fold change of expression in the PTI and ETI plants, as compared to control plants infiltrated with media, was 0.42 for PTI, 0.35 for ETI-IpiO, and 0.07 for ETI-Avr2, $p=0.009$. It is likely that this decrease reflects a changed need for active amino acid metabolism during immunity [46].

We found some proteases, subtilases, and PR proteins to be decreased in ETI reactions. They belonged to protein families that have members that previously have been reported to increase in different types of immunity. Two possible explanations are that these specific family member proteins may have translocated to a different subcellular compartment, where they will be active during the immune response, or that these family members have a negative role. It is known that the subtilisin type protease AtSBT5.2 gene can produce two alternative proteins, a secreted protease AtSBT5.2 (a) and an intracellular AtSBT5.2 (b) protein. This latter form of the protein interferes with a defense gene-inducing transcription factor, leading to suppression of HR and impaired resistance [47].

A protein annotated as aspartic proteinase nepenthesin-1 (PGSC0003DMP400032897) displayed decreased abundance during the ETI-IpiO interaction only. In another proteomics study, its closest homolog in black pepper also showed decreased abundance when challenged with Phytophthora capsici [48]. These findings suggest that decreased abundance of an aspartic proteinase is possibly involved in plant defense mechanisms. Furthermore, we have identified a Lysyl-tRNA synthetase (PGSC0003DMP400046710) and a eukaryotic translation initiation factor (PGSC0003DMP400013944) which decreased in abundance during the ETI-IpiO condition.

In the ETI-Avr2 interaction, 24 proteins displayed decreased abundance specifically. Among them, four histones decreased: histone H1, histone H2A.1, histone H2A, and histone H1F. It is interesting that all histones identified in this study display a distinct change in abundance in only one type of immune response. One possible explanation is that these histones may have undergone post-translational modifications that have changed their affinity for chromatin, making them less likely to be isolated by our sample preparation procedure. Histones undergo a large number of post-translational modifications, such as methylation and acetylation. These modifications can affect the degree of chromatin relaxation, and thus may change how histones bind to chromatin. 
Table 4. Proteins from two ETI interactions with decreased abundance (ETI-IpiO and ETI-Avr2), 18 hpi (hours post infiltration). A comparison is made between immune-treated plants and the control plants infiltrated with medium only. All values are in $\log 2$ fold. Non-significant $p$ values are indicated by NA. All $p$-values $<0.01$ are shown in the table.

\begin{tabular}{|c|c|c|c|}
\hline \multirow{2}{*}{ Protein ID } & \multirow{2}{*}{ Protein Name } & \multicolumn{2}{|c|}{ Degree of Regulation $(\log 2)$} \\
\hline & & ETI (Blb1-IpiO) & ETI (AVR2-R2) \\
\hline E1AXT5 & Apoplastic invertase & -0.40 & -0.49 \\
\hline P49316 & Catalase isozyme 2 & -0.66 & -0.63 \\
\hline PGSC0003DMP400032195 & $\begin{array}{l}\text { SWIb domain-containing } \\
\text { protein }\end{array}$ & -0.46 & -0.63 \\
\hline PGSC0003DMP400000868 & Actin-11 & -0.70 & -0.65 \\
\hline O49074 & $\begin{array}{l}\text { Ribulose bisphosphate } \\
\text { carboxylase }\end{array}$ & -0.64 & -0.66 \\
\hline Q5MA02 & $\begin{array}{c}\text { Cytochrome c oxidase } \\
\text { subunit } 2\end{array}$ & -0.91 & -0.66 \\
\hline PGSC0003DMP400000788 & $\begin{array}{l}\text { Inner membrane protein } \\
\text { PPF-1 }\end{array}$ & -0.62 & -0.73 \\
\hline PGSC0003DMP400010545 & O-glycosyl hydrolase & -0.56 & -0.74 \\
\hline PGSC0003DMP400046981 & Kunitz trypsin inhibitor & -0.94 & -0.75 \\
\hline PGSC0003DMP400025093 & ATP-dependent Clp protease & -0.66 & -0.75 \\
\hline PGSC0003DMP400039372 & AGO4-2 & -0.63 & -0.82 \\
\hline Q42871 & Endoglucanase & -1.64 & -0.82 \\
\hline PGSC0003DMP400030598 & Ribonucleoprotein & -0.96 & -0.86 \\
\hline A0A024J2E4 & $\begin{array}{l}\text { Putative transcription } \\
\text { activator TraR }\end{array}$ & -0.90 & -1.22 \\
\hline PGSC0003DMP400040149 & $\begin{array}{l}\text { Short chain alcohol } \\
\text { dehydrogenase }\end{array}$ & -1.23 & -0.92 \\
\hline PGSC0003DMP400019158 & Aspartate aminotransferase & -0.79 & -0.93 \\
\hline PGSC0003DMP400017124 & $\begin{array}{l}\text { Ferredoxin-dependent } \\
\text { glutamate synthase } 1\end{array}$ & -1.24 & -0.95 \\
\hline PGSC0003DMP400018521 & Subtilase & -0.97 & -1.04 \\
\hline PGSC0003DMP400042601 & Gene of unknown function & -0.66 & -1.04 \\
\hline D0EJY9 & $\begin{array}{l}\text { Molecular chaperone } \\
\text { Hsp90-3 }\end{array}$ & -1.29 & -1.08 \\
\hline P32811 & Alpha-glucan phosphorylase & -1.47 & -1.10 \\
\hline Q1EBW2 & Aspartate aminotransferase & -0.91 & -1.13 \\
\hline PGSC0003DMP400018523 & Subtilase & -0.84 & -1.13 \\
\hline PGSC0003DMP400015799 & $\begin{array}{c}\text { Basic 7S globulin } 2 \text { small } \\
\text { subunit }\end{array}$ & -0.98 & -1.15 \\
\hline A7LKN1 & TAO1 & -1.12 & -1.16 \\
\hline F4HRC1 & THO complex subunit $5 \mathrm{~A}$ & -0.87 & -1.18 \\
\hline PGSC0003DMP400068875 & Threonyl-tRNA synthetase & -1.21 & -1.19 \\
\hline PGSC0003DMP400039983 & Protein SIS1 & -1.81 & -1.20 \\
\hline PGSC0003DMP400014905 & $\begin{array}{l}\text { Polygalacturonase inhibiting } \\
\text { protein }\end{array}$ & -0.88 & -1.24 \\
\hline PGSC0003DMP400011487 & $\begin{array}{l}\text { GTP-binding nuclear protein } \\
\text { Ran1 }\end{array}$ & -1.15 & -1.29 \\
\hline PGSC0003DMP400007007 & P69B protein & -1.80 & -1.42 \\
\hline PGSC0003DMP400033260 & Xylem serine proteinase 1 & -2.19 & -1.59 \\
\hline PGSC0003DMP400040582 & $\begin{array}{l}\text { Biotin carboxylase carrier } \\
\text { protein }\end{array}$ & -1.18 & -1.61 \\
\hline PGSC0003DMP400032609 & Amidase family protein & -0.50 & NA \\
\hline PGSC0003DMP400044937 & Serine carboxypeptidase & -0.74 & NA \\
\hline PGSC0003DMP400034518 & Chitinase & -0.77 & NA \\
\hline PGSC0003DMP400013944 & $\begin{array}{l}\text { Eukaryotic translation } \\
\text { initiation factor } 4 \mathrm{~F}\end{array}$ & -0.88 & NA \\
\hline PGSC0003DMP400046710 & Lysyl-tRNA synthetase & -0.90 & NA \\
\hline PGSC0003DMP400002882 & Glycine-rich protein 2 & -0.90 & NA \\
\hline PGSC0003DMP400001015 & Class III peroxidase & -0.93 & NA \\
\hline PGSC0003DMP400012991 & Apyrase 3 & -0.93 & NA \\
\hline PGSC0003DMP400043401 & $\begin{array}{l}\text { NADPH:protochlorophyllide } \\
\text { oxidoreductase }\end{array}$ & -1.00 & NA \\
\hline
\end{tabular}


Table 4. Cont.

\begin{tabular}{|c|c|c|c|}
\hline \multirow{2}{*}{ Protein ID } & \multirow{2}{*}{ Protein Name } & \multicolumn{2}{|c|}{ Degree of Regulation $(\log 2)$} \\
\hline & & ETI (Blb1-IpiO) & ETI (AVR2-R2) \\
\hline F4IFG1 & Dynamin related protein & -1.02 & NA \\
\hline PGSC0003DMP400056894 & P69B protein & -1.32 & NA \\
\hline PGSC0003DMP400012143 & Gene of unknown function & -1.39 & NA \\
\hline PGSC0003DMP400009992 & Beta tubulin & -1.43 & NA \\
\hline PGSC0003DMP400036604 & $\begin{array}{l}\text { WPP domain-associated } \\
\text { protein }\end{array}$ & -1.45 & NA \\
\hline PGSC0003DMP400033261 & Xylem serine proteinase 1 & -1.55 & NA \\
\hline PGSC0003DMP400032897 & $\begin{array}{l}\text { Aspartic proteinase } \\
\text { nepenthesin-1 }\end{array}$ & -2.48 & NA \\
\hline B9JM45 & $\begin{array}{l}\text { 6-Phosphogluconate } \\
\text { dehydrogenase }\end{array}$ & NA & -1.31 \\
\hline PGSC0003DMP400020641 & $\begin{array}{c}\text { CBL-interacting protein } \\
\text { kinase } 13\end{array}$ & NA & 0.71 \\
\hline Q8W174 & Peroxidase & NA & 0.70 \\
\hline PGSC0003DMP400016778 & Periplasmic beta-glucosidase & NA & 0.62 \\
\hline Q2MI54 & $30 S$ ribosomal protein $\mathrm{S} 7$ & NA & 0.62 \\
\hline PGSC0003DMP400045032 & Pectinesterase & NA & 0.60 \\
\hline E2I6L5 & Polyubiquitin & NA & 0.59 \\
\hline PGSC0003DMP400023756 & GDSL-lipase protein & NA & 0.58 \\
\hline PGSC0003DMP400009676 & $\begin{array}{l}\text { Eukaryotic translation } \\
\text { initiation factor } 2 \text { family } \\
\text { protein }\end{array}$ & NA & 0.58 \\
\hline PGSC0003DMP400045566 & 50 S ribosomal protein L19-2 & NA & 0.58 \\
\hline PGSC0003DMP400064549 & Subtilisin-like protease & NA & 0.55 \\
\hline Q3LS00 & Polygalacturonase inhibitor & NA & 0.54 \\
\hline C0Z2Q9 & AT3G13920 protein & NA & 0.53 \\
\hline PGSC0003DMP400014290 & AMP dependent CoA ligase & NA & 0.53 \\
\hline PGSC0003DMP400009317 & Superoxide dismutase & NA & 0.53 \\
\hline F4JWP8 & $\begin{array}{l}\text { Homeobox protein } \\
\text { knotted-1-like } 3\end{array}$ & NA & 0.53 \\
\hline Q9LXG7 & $\begin{array}{l}\text { Aldose 1-epimerase family } \\
\text { protein }\end{array}$ & NA & 0.52 \\
\hline PGSC0003DMP400006170 & $60 \mathrm{~S}$ ribosomal protein L7A & NA & 0.51 \\
\hline Q43286 & Histone $\mathrm{H} 2 \mathrm{~A}$ & NA & 0.50 \\
\hline PGSC0003DMP400042811 & $60 S$ ribosomal protein L18 & NA & 0.41 \\
\hline PGSC0003DMP400002092 & Histone H1F & NA & 0.37 \\
\hline PGSC0003DMP400011213 & Beta-glucosidase 01 & NA & 0.32 \\
\hline PGSC0003DMP400042879 & Histone H2A.1 & NA & 0.26 \\
\hline PGSC0003DMP400034568 & Histone H1 & NA & 0.07 \\
\hline
\end{tabular}

\subsection{Protein Methylation}

Protein methylation on lysine and arginine residues is a tightly controlled process that contributes to the regulation of protein function in several different ways. Lysine and arginine methylation is catalyzed by methyltransferases and demethylases. One of the most well-characterized biological roles of protein methylation is the effect of methylation of histones. This modification can regulate gene activity, either positively or negatively. We observed both a reduction of lysine-specific histone demethylase in PTI and a specific decrease in abundance of a number of histones in ETI-Avr2. Methylation is known to affect binding to chromatin. Due to this, we decided to investigate protein methylation in our dataset. We identified 40 high confidence methylated peptides from 34 methylated proteins in our samples (Table 5, supplementary material 1). For example, we identified one histone methylation, on Lys 116 of histone H3 (H3116me). This lysine residue is located in the protein core of the histone, and not in the N-terminal part where most well-characterized methylations are found [27]. We have not been able to find any publication describing methylation of histone $\mathrm{H} 3$ on this site, making this the first observation of this particular methylation site. Notable among the other methylated proteins were histone acetyltransferase, which catalyzes the acylation of histones. This is an important step in chromatin relaxation, leading to increased gene transcription, as well as a number of chloroplast 
proteins such as rubisco large chain and chlorophyll a-b binding protein, which have previously been shown to be methylated in Arabidopsis [49].

We identified other methylated proteins that changed in abundance during immune reactions, including UPF0497 membrane protein (CASP-protein) (PGSC0003DMP400046973) and serine hydroxymethyltransferase (P50433), which both increased in the ETI conditions. The UPF0497 membrane protein has been discussed earlier, and it is possible that the activity of this protein is regulated by methylation, even though we have not found any report of this in the literature. Metabolism and methylation status are linked in several ways in plants [50]. The serine hydroxymethyltransferase catalyzes the methylation of tetrahydrofolate in the folate cycle. This methyl group can be transferred into the methionine cycle, where it is used to produce S-adenosylmethionine (SAM), which is the main methyl donor in protein and DNA methylation reactions, linking serine hydroxymethyltransferase to methylation reactions [51]. The inhibition of the folate cycle has been demonstrated to cause reduced DNA and histone methylation in Arabidopsis [52]. Methionine synthetic pathways have also been shown to be upregulated during the plant immune response [53].

Table 5. Examples of methylated peptides identified in the analysis (all methylated peptides are shown in the supplementary material 1. Regulation in immunity: whether the protein was identified as regulated in the quantitative analysis. Sequence: The sequence of the modified peptide, underlined is the methylated site. The position and nature of the modified amino acid are indicated by a number. In the cases where a methylated peptide has been identified but the site not determined, this is indicated by NA.

\begin{tabular}{|c|c|c|c|c|}
\hline External Id & Protein Name & $\begin{array}{l}\text { Regulation in } \\
\text { Immunity }\end{array}$ & Sequence & Modification \\
\hline P50433 & $\begin{array}{c}\text { Serine } \\
\text { hydroxymethyltransferase }\end{array}$ & Up in ETI & YSEGYPGAR & Dimethyl(R) \\
\hline P25079 & $\begin{array}{l}\text { Ribulose bisphosphate } \\
\text { carboxylase large chain }\end{array}$ & Up in ETI & $\begin{array}{l}\text { DTDILAAFR } \\
\text { DITLGFVDLLR }\end{array}$ & $\begin{array}{l}\text { Dimethyl(R) } \\
\text { Dimethyl(R) }\end{array}$ \\
\hline \multirow[t]{2}{*}{ Q2VEH0 } & \multirow[t]{2}{*}{$\begin{array}{l}\text { ATP synthase subunit } \\
\text { beta }\end{array}$} & \multirow[t]{2}{*}{ Up in PTI } & $\begin{array}{c}\text { MRINPTTSGSGVSTLEK } \\
\text { FLSQPFFVAEVFTGSPGKYVGLAETIR }\end{array}$ & $\begin{array}{c}\text { Methyl(R), } \\
\text { Oxidation(M) } \\
\text { Dimethyl(R) }\end{array}$ \\
\hline & & & FLSQPFFVAEVFTGSPGKYVGLAETIR & $\begin{array}{l}\text { Methyl(K), } \\
\text { Methyl(R) }\end{array}$ \\
\hline Q9LEB0 & Pectinesterase & Down in PTI & SNTIITGSR & Methyl(R) \\
\hline PGSC0003DMP400046973 & $\begin{array}{l}\text { UPF0497 membrane } \\
\text { protein }\end{array}$ & $\begin{array}{l}\text { Up in PTI and } \\
\text { ETI }\end{array}$ & YVNGFVDTIETTGIDTFEEL툐 & Dimethyl(R) \\
\hline PGSC0003DMP400002077 & Histone H3.2 & NA & FQSSAVAALQEAAEAYLVGVFEDTNLCAIHAK & Methyl(K) \\
\hline
\end{tabular}

\section{Materials and Methods}

\subsection{Plants and Infiltration}

The methodology used in this study has been thoroughly described in our previous study by Burra et al. [15]. Three different types of Solanum tuberosum cv. Désirée were used in this study, namely the wild type Désirée plants, AO1-22 (Désirée with the Rpi-Blb1 resistance gene) and T16 (Désirée with the R2-type resistance gene) [54-56]. Plants were grown in vitro for 2 weeks (MS media with vitamins, $16 \mathrm{~h}$ of light, $23^{\circ} \mathrm{C}$ day temperature, $18^{\circ} \mathrm{C}$ night temperature) followed by 4 weeks in soil ( $22^{\circ} \mathrm{C}, 16 \mathrm{~h}$ of light), as described in Abreha et al. [54] and Burra et al. [15]. The Agrobacterium AGL1 strains were grown on $10 \mathrm{~mL}$ YEB medium supplemented with $1 \mu \mathrm{L}$ of $200 \mathrm{mM}$ acetosyringone, $100 \mu \mathrm{L}$ of $1 \mathrm{M}$ MES buffer and antibiotics for $24 \mathrm{~h}$ at $28^{\circ} \mathrm{C}, 200 \mathrm{rpm}$ until an OD600 of 1 , as explained in Du et al. [57] and Burra et al. [15]. After this, the bacteria was re-suspended in infiltration media ( $5 \mathrm{~g} / \mathrm{L}$ MS salts, $1.95 \mathrm{~g} / \mathrm{L}$ MES, $20 \mathrm{~g} / \mathrm{L}$ sucrose, $200 \mu \mathrm{M}$ acetosyringone, $\mathrm{pH}$ 5.6). Infiltration with infiltration media occurred only for the control or bacterial suspension with OD600 $=0.3$ and was done on the abaxial surface of the leaflets of four plants per genotype, as described by Burra et al. [15]. The Agrobacterium transformed with either an empty vector into wild type plants (the PTI condition), the IpiO effector gene into AO1-22 plants (the IpiO-Blb1 condition), or the Avr2 effector gene into T16 (the Avr2-R2 condition). The macroscopic cell death phenotype was assessed at 18, 42, and $72 \mathrm{~h}$ post infiltration (hpi), and the whole experiment was repeated twice. The plants showed no visible 
symptoms at $18 \mathrm{hpi}$, while an even cell death was found in both ETI interactions at 42 and $72 \mathrm{hpi}$ (data not shown, Burra et al. [15]). This study has followed local, national, and international guidelines and legislations, and all required or proper permissions and/or licenses were obtained.

\subsection{Protein Fractionation}

Eight biological replicates originating from two independent experiments were processed. Each sample consisted of two stabs from two leaflets $18 \mathrm{~h}$ post infiltration (hpi), corresponding to $100 \mathrm{mg}$ fresh weight. Each sample was cooled on ice and put in a $1.5 \mathrm{~mL}$ Eppendorf tube with sea sand, before processing with a Subcellular Protein Fractionation Kit for Tissues (ThermoFisher Scientific, Waltham, MA, USA, Catalog No. 87790) with minor modifications (see below, and Burra et al. [15]). Briefly, proteins were consecutively extracted in four different buffers included in the kit, and the final supernatants were frozen at $-80^{\circ} \mathrm{C}$ until further use. Each leaf sample was disrupted using pestle sticks in $1 \mathrm{~mL}$ ice-cold cellular extraction buffer (CEB). The sample was then passed through tissue and centrifuged at $500 \times g$ for $5 \mathrm{~min}$ at $4{ }^{\circ} \mathrm{C}$. The $500 \times g$ CEB pellet was washed and centrifuged once with $\mathrm{CEB}$, and ice-cold membrane extraction buffer (MEB) was added to the washed pellet. The pellet was then vortexed and incubated at $4{ }^{\circ} \mathrm{C}$ for $10 \mathrm{~min}$ with gentle mixing. After incubation, the solution was centrifuged at $3000 \times g$ for $5 \mathrm{~min}$. The supernatant was cleared by re-centrifugation at $16,000 \times g$ for $10 \mathrm{~min}$ at $4{ }^{\circ} \mathrm{C}$ and the supernatant saved as the membrane fraction, which is the fraction that was analyzed in Burra et al. [15]. The pellet obtained after the $3000 \times g$ centrifugation was washed once with MEB and centrifuged. To the resulting pellet, ice-cold nuclear extraction buffer (NEB) was added, and the sample was vortexed and incubated for $30 \mathrm{~min}$ at $4{ }^{\circ} \mathrm{C}$ with gentle mixing. After incubation the supernatant was cleared by re-centrifugation at $16,000 \times g$ for $10 \mathrm{~min}$ at $4{ }^{\circ} \mathrm{C}$ and the supernatant was analyzed in this paper.

\subsection{Tryptic Digestion and Mass Spectrometry}

Proteins were separated on a 14\% SDS-PAGE gel. The whole lane was removed and washed, and the proteins were digested using trypsin (Promega Trypsin Gold, Madison, WI, USA, Mass Spectrometry Grade Trypsin Gold, Catalog number: V5280). The digests were desalted by C18-based spin columns (The Nest Group Inc., Southborough, MA, USA) as described in Chawade et al. (2016), and analyzed with the application of an Eksigent nanoLC2D HPLC system with an online LTQ Orbitrap XL ETD [58]. The full procedure is detailed in Burra et al. [15].

\subsection{Peptide Data Analysis}

The raw data from the Orbitrap was converted to Mascot generic files (mgf) with ProteoWizard [59]. A protein database consisting of solanum proteins from UniProt (www.uniprot.org), downloaded 24 August 2011, protein sequences from the Potato Genome Project [60] and the Agrobacterium proteins from UniProt, downloaded 10 March 2015, concatenated with an equal size decoy database (random protein sequences with conserved protein length and amino acid distribution, in total 36,512 target and decoy protein entries), was generated using a modified version of the decoy.pl script from MatrixScience (http://www.matrixscience.com/help/decoy_help.html) [61]. The mgf files were used for searches against this database with Mascot version 2.3.01 in the Proteios software environment [62]. Search tolerances were $7 \mathrm{ppm}$ for precursors and 0.5 Da for MS/MS fragments. For the searches used for quantitative analyses, one missed cleavage was allowed, and carbamidomethylation of cysteine residues was used as fixed modification and oxidation of methionines as variable modification. For the identification of methylated proteins, carbamidomethylation of cysteine was used as a fixed modification, while oxidation of methionines, mono-, di-, and trimethylation of lysine and mono-, $\mathrm{di}-$, and trimethylation of arginine were used as variable modifications. Search results were exported from Mascot as XML, including query level results, with a modification to the export script to include protein accession numbers, and also for the query (spectrum) level results. The results were imported to Proteios, where q values were calculated using the target-decoy method described by Käll et al. [63]. 
The search results were then filtered at a peptide-spectrum match q-value of 0.01 to obtain a false discovery rate of $1 \%$ in the filtered list. For quantitative peptide analysis, a label-free approach based on precursor ion intensities was used [64], with all data processing steps performed within Proteios. MS1 peptide feature detection was performed using Dinosaur [65], while the other data processing steps were performed in Proteios, and subsequent feature matching and alignment between LC-MS/MS was run with a previously described workflow [66]. The resulting peptide data were normalized using Loess-G normalization [67] in the Normalyzer software [68]. The normalized data were analyzed using DanteR [69]. For methylated peptides, a separate FDR calculation was performed. The matches against methylated peptides were sorted by order of decreasing Mascot score, and for each peptide the total number of peptides with an equal or higher score was calculated. The methylFDR for a given hit was then calculated by dividing the number of decoy hits by the total number of hits. To produce a final list of methylated peptides, the hits were then filtered at a methylFDR value of $<0.01$. To increase the confidence of our final list, we excluded tri- and dimethylated lysines. Trimethylated lysine was excluded since it is isobaric with acetylated lysine. Dimethylated lysine is isobaric with arginine and was excluded since there is a risk that a spectrum from the fragmentation of an arginine-containing peptide may be misidentified as that of a peptide containing dimethylated lysine, if such a peptide is present in a homologous protein also included in the database. We also required that all peptides should be the top hit for their respective spectrum, to decrease the risk of misidentification due to sequence differences that are isobaric with methylation (i.e. $\mathrm{I} / \mathrm{L}$ to $\mathrm{V}$ ). In order to be able to differentiate between peptides where the methylation site was determined and peptides that were methylated but the methylation site could not be identified, we adopted the Mascot delta score method [70], with a DS $>10$ regarded as an identified methylation site. The data were deposited in the PRIDE database (PXD012576).

\subsection{RNA Extraction and Quantitative RT-PCR}

RNA from potato leaf tissue samples was isolated using the Qiagen RNeasy Plant Mini kit, according to the manufacturer's protocol. RNA was quantified using Nanodrop Spectrophotometry (Table S1, Figure S2), and 500 ng RNA was used for cDNA synthesis using SuperScript III (Thermofisher, Waltham, MA, USA, Catalog No. 18080051) with oligo dT primers. cDNAs were diluted 10 times with nuclease-free water prior to qPCR analysis in a CFX96 real-time thermal cycler (Bio-Rad). qPCR was performed on four biological and three technical replicates using Platinum SYBR Green qPCR SuperMix kit (Thermofisher, Waltham, MA, USA, Catalog No. 11733038). All qPCR data were analyzed using the Pfaffl-method [71], with expression normalized to the housekeeping gene Ef $1 \alpha$ and fold change calculated using primer-pair amplification efficiencies determined from standard curves. A one-way ANOVA and F-test were used to analyze the data. Primers were designed using Primer3 [72], with sequence information from http://solanaceae.plantbiology.msu.edu. The primers were the following: for the housekeeping gene Ef1 $\alpha \_F$ ( $5^{\prime}$ GAACTGTCCCTGTTGGTCGT $\left.3^{\prime}\right)$ and Ef1 $\alpha \_R\left(5^{\prime}\right.$ GGGTCATCCTTGGAGTTTGA $\left.3^{\prime}\right)$, for ferredoxin-dependent glutamate synthase 1 , P17124_F (5' GGATTGGTTATGCGGCAACT 3') and P17124_R (5' TTTGCGATAAAACCGACCC 3'), and for xylem serine proteinase 1, P12806_F (5' TCCCCTCTTGGCTTCATGT 3'), P12806_R (5' GCTTGATGAGGGGTGAGAA 3'). Primer efficiencies, agarose gel analysis of PCR products, and generated melting curves are shown in Figure S2.

\section{Conclusions}

In this paper, we described an analysis of one PTI and two ETI models in potatoes and compared their resulting changes in protein abundance. In PTI, germin, proteases, and a CASP-like protein increased, all in line with what is expected during the initial stages of immunity. Sterol carrier protein 2 increased in abundance in all three immune reactions, which is interesting since $P$. infestans and other oomycete pathogens rely on the host for sterols. Several proteins with RNA binding activity had higher abundance in ETI, in line with increasing evidence demonstrating a role for RNA-related proteins in 
regulating plant immunity. In the ETI interactions, several catalase proteins were found to be higher in abundance, which can perhaps be linked to ROS tolerance mechanisms. We showed that four histones decrease in abundance, specifically in the ETI-Avr2 interaction, and that no histones display changes in abundance in the other immune reactions. We also demonstrated the first proteomic analysis of protein methylation in potatoes, including a previously unidentified methylation site on histone $\mathrm{H} 3$ and the methylation of serine hydroxymethyltransferase, which increases in the ETI interaction. The serine hydroxymethyltransferase participates in the pathway producing the main methyl donor in methylation reactions.

Data from our earlier proteomics study on one membrane-associated protein fraction [15] indicated that specific protein differences between different ETIs are in a similar range to the differences between PTI and ETI at downstream signaling, before the onset of HR. The current data support the idea that downstream signaling differs between different ETIs to a similar degree as ETI differs from PTI. Our methods and results could be used in future mechanistic-based pre-breeding and prediction of sustainable combinations of resistance genes by, for example, potato single reaction monitoring SRM [58]. Resistance genes are known to be problematic with regards to durability; the pathogen can overcome this type of resistance. Therefore, efforts are being made to combine different sources of resistance [73]. Criteria for selection of combinations of resistance sources are the host range and how broad it is, and a future selection criterion can be using genes or genetic material with different resistance mechanisms. This study lays the foundation for the last criterion and could be used even if the gene is unknown by combining different down-stream mechanisms.

Supplementary Materials: Supplementary materials can be found at http://www.mdpi.com/1422-0067/20/19/ 4726/s1.

Author Contributions: E.A., S.R., M.L., D.B. contributed to conception and design of the study; S.R., M.A.Z., D.B., M.L. made the laboratory part, and F.L. organized the database. S.R., E.A. and M.A.Z. wrote the manuscript. All authors contributed to the manuscript, as well as read and approved the submitted version.

Funding: This research was funded by the Swedish Foundation for Environmental Strategic Research (Mistra Biotech), the Swedish Research Council for Environment, Agricultural Sciences and Spatial Planning (2015-442) as well as the Swedish Foundation for Strategic Research.

Acknowledgments: Mia Mogren is acknowledged for excellent technical support.

Conflicts of Interest: The submitted work was carried out with no presence of any personal, professional or financial relationships that could potentially be construed as a conflict of interest.

\section{Abbreviations}

$\begin{array}{ll}\text { PAMP } & \text { Pathogen-associated molecular pattern } \\ \text { PRR } & \text { Pattern-recognition receptors } \\ \text { PTI } & \text { PAMP-triggered immunity } \\ \text { ROS } & \text { Reactive oxygen species } \\ \text { ETS } & \text { Effector-triggered susceptibility } \\ \text { ETI } & \text { Effector-triggered immunity } \\ \text { HR } & \text { Hypersensitive response }\end{array}$

\section{References}

1. Zipfel, C. Pattern-recognition receptors in plant innate immunity. Curr. Opin. Immunol. 2008, 20, 10-16. [CrossRef] [PubMed]

2. Baxter, A.; Mittler, R.; Suzuki, N. ROS as key players in plant stress signalling. J. Exp. Bot. 2013, 65, 1229-1240. [CrossRef] [PubMed]

3. Pitzschke, A.; Schikora, A.; Hirt, H. MAPK cascade signalling networks in plant defence. Curr. Opin. Plant Biol. 2009, 12, 421-426. [CrossRef] [PubMed]

4. Jones, J.D.G.; Dangl, J.L. The plant immune system. Nature 2006, 444, 323. [CrossRef] [PubMed]

5. Coll, N.S.; Epple, P.; Dangl, J.L. Programmed cell death in the plant immune system. Cell Death Differ. 2011, 18, 1247. [CrossRef] [PubMed] 
6. Thomma, B.P.H.J.; Nürnberger, T.; Joosten, M.H.A.J. Of PAMPs and Effectors: The Blurred PTI-ETI Dichotomy. Plant Cell 2011, 23, 4. [CrossRef]

7. Leibman-Markus, M.; Pizarro, L.; Schuster, S.; Lin, Z.J.D.; Gershony, O.; Bar, M.; Coaker, G.; Avni, A. The intracellular nucleotide-binding leucine-rich repeat receptor (SINRC4a) enhances immune signalling elicited by extracellular perception. Plant Cell Environ. 2018, 41, 2313-2327. [CrossRef]

8. Lee, S.; Fu, F.; Xu, S.; Lee, S.Y.; Yun, D.-J.; Mengiste, T. Global Regulation of Plant Immunity by Histone Lysine Methyl Transferases. Plant Cell 2016, 28, 1640. [CrossRef]

9. Haverkort, A.J.; Struik, P.C.; Visser, R.G.F.; Jacobsen, E. Applied Biotechnology to Combat Late Blight in Potato Caused by Phytophthora Infestans. Potato Res. 2009, 52, 249-264. [CrossRef]

10. Champouret, N.; Bouwmeester, K.; Rietman, H.; van der Lee, T.; Maliepaard, C.; Heupink, A.; van de Vondervoort, P.J.I.; Jacobsen, E.; Visser, R.G.F.; van der Vossen, E.A.G.; et al. Phytophthora infestans Isolates Lacking Class I ipiO Variants Are Virulent on Rpi-blb1 Potato. Mol. Plant-Microbe Interact. 2009, 22, 1535-1545. [CrossRef]

11. Lokossou, A.A.; Park, T.-h.; van Arkel, G.; Arens, M.; Ruyter-Spira, C.; Morales, J.; Whisson, S.C.; Birch, P.R.J.; Visser, R.G.F.; Jacobsen, E.; et al. Exploiting Knowledge of R/Avr Genes to Rapidly Clone a New LZ-NBS-LRR Family of Late Blight Resistance Genes from Potato Linkage Group IV. Mol. Plant-Microbe Interact. 2009, 22, 630-641. [CrossRef]

12. Vleeshouwers, V.G.A.A.; Rietman, H.; Krenek, P.; Champouret, N.; Young, C.; Oh, S.-K.; Wang, M.; Bouwmeester, K.; Vosman, B.; Visser, R.G.F.; et al. Effector Genomics Accelerates Discovery and Functional Profiling of Potato Disease Resistance and Phytophthora Infestans Avirulence Genes. PLoS ONE 2008, 3, e2875. [CrossRef]

13. Turnbull, D.; Yang, L.; Naqvi, S.; Breen, S.; Welsh, L.; Stephens, J.; Morris, J.; Boevink, P.C.; Hedley, P.E.; Zhan, J.; et al. RXLR Effector AVR2 Up-Regulates a Brassinosteroid-Responsive bHLH Transcription Factor to Suppress Immunity. Plant Physiol. 2017, 174, 356. [CrossRef]

14. Saunders, D.G.O.; Breen, S.; Win, J.; Schornack, S.; Hein, I.; Bozkurt, T.O.; Champouret, N.; Vleeshouwers, V.G.A.A.; Birch, P.R.J.; Gilroy, E.M.; et al. Host Protein BSL1 Associates with Phytophthora infestans RXLR Effector AVR2 and the Solanum demissum Immune Receptor R2 to Mediate Disease Resistance. Plant Cell 2012, 24, 3420. [CrossRef]

15. Burra, D.D.; Lenman, M.; Levander, F.; Resjö, S.; Andreasson, E. Comparative Membrane-Associated Proteomics of Three Different Immune Reactions in Potato. Int. J. Mol. Sci. 2018, 19, 538. [CrossRef]

16. Van Aubel, G.; Buonatesta, R.; Van Cutsem, P. Cos-oga, a new oligosaccharidic elicitor that induces protection against a wide range of plant pathogens. IOBC-WPRS Bull. 2013, 89, 403-407.

17. Rayapuram, C.; Jensen, M.K.; Maiser, F.; Shanir, J.V.; Hornshøj, H.; Rung, J.H.; Gregersen, P.L.; Schweizer, P.; Collinge, D.B.; Lyngkjær, M.F. Regulation of basal resistance by a powdery mildew-induced cysteine-rich receptor-like protein kinase in barley. Mol. Plant Pathol. 2012, 13, 135-147. [CrossRef]

18. Xiao, C.; Gao, J.; Zhang, Y.; Wang, Z.; Zhang, D.; Chen, Q.; Ye, X.; Xu, Y.; Yang, G.; Yan, L.; et al. Quantitative Proteomics of Potato Leaves Infected with Phytophthora infestans Provides Insights into Coordinated and Altered Protein Expression during Early and Late Disease Stages. Int. J. Mol. Sci. 2019, 20, 136. [CrossRef]

19. Afitlhile, M.M.; Fukushige, H.; Nishimura, M.; Hildebrand, D.F. A defect in glyoxysomal fatty acid $\beta$-oxidation reduces jasmonic acid accumulation in Arabidopsis. Plant Physiol. Biochem. 2005, 43, 603-609. [CrossRef]

20. Davidson, R.M.; Reeves, P.A.; Manosalva, P.M.; Leach, J.E. Germins: A diverse protein family important for crop improvement. Plant Sci. 2009, 177, 499-510. [CrossRef]

21. Lane, B.G. Oxalate, Germins, and Higher-Plant Pathogens. IUBMB Life 2002, 53, 67-75. [CrossRef]

22. Grosse-Holz, F.; Kelly, S.; Blaskowski, S.; Kaschani, F.; Kaiser, M.; van der Hoorn, R.A.L. The transcriptome, extracellular proteome and active secretome of agroinfiltrated Nicotiana benthamiana uncover a large, diverse protease repertoire. Plant Biotechnol. J. 2018, 16, 1068-1084. [CrossRef]

23. Roppolo, D.; De Rybel, B.; Tendon, V.D.; Pfister, A.; Alassimone, J.; Vermeer, J.E.M.; Yamazaki, M.; Stierhof, Y.-D.; Beeckman, T.; Geldner, N. A novel protein family mediates Casparian strip formation in the endodermis. Nature 2011, 473, 380. [CrossRef]

24. Serrazina, S.; Santos, C.; Machado, H.; Pesquita, C.; Vicentini, R.; Pais, M.S.; Sebastiana, M.; Costa, R. Castanea root transcriptome in response to Phytophthora cinnamomi challenge. Tree Genet. Genomes 2015, 11, 6. [CrossRef] 
25. Nes, W.D. Biosynthesis and Requirement for Sterols in the Growth and Reproduction of Oomycetes. In Ecology and Metabolism of Plant Lipids; American Chemical Society: Washington, DC, USA, 1987; Volume 325, pp. 304-328.

26. Thomas, E.L.; Van der Hoorn, R.A.L. Ten Prominent Host Proteases in Plant-Pathogen Interactions. Int. J. Mol. Sci. 2018, 19, 639. [CrossRef]

27. Greer, E.L.; Shi, Y. Histone methylation: A dynamic mark in health, disease and inheritance. Nat. Rev. Genet. 2012, 13, 343. [CrossRef]

28. $\mathrm{Ng}$, A.; Xavier, R.J. Leucine-rich repeat (LRR) proteins: Integrators of pattern recognition and signaling in immunity. Autophagy 2011, 7, 1082-1084. [CrossRef]

29. Padmanabhan, M.; Cournoyer, P.; Dinesh-Kumar, S.P. The leucine-rich repeat domain in plant innate immunity: A wealth of possibilities. Cell. Microbiol. 2009, 11, 191-198. [CrossRef]

30. Bengtsson, T.; Weighill, D.; Proux-Wéra, E.; Levander, F.; Resjö, S.; Burra, D.D.; Moushib, L.I.; Hedley, P.E.; Liljeroth, E.; Jacobson, D.; et al. Proteomics and transcriptomics of the BABA-induced resistance response in potato using a novel functional annotation approach. BMC Genom. 2014, 15, 315. [CrossRef]

31. Lionetti, V.; Cervone, F.; Bellincampi, D. Methyl esterification of pectin plays a role during plant-pathogen interactions and affects plant resistance to diseases. J. Plant Physiol. 2012, 169, 1623-1630. [CrossRef]

32. Marty, P.; Jouan, B.; Bertheau, Y.; Vian, B.; Goldberg, R. Charge density in stem cell walls of Solanum tuberosum genotypes and susceptibility to blackleg. Phytochemistry 1997, 44, 1435-1441. [CrossRef]

33. McMillan, G.P.; Hedley, D.; Fyffe, L.; Pérombelon, M.C.M. Potato resistance to soft-rot erwinias is related to cell wall pectin esterification. Physiol. Mol. Plant Pathol. 1993, 42, 279-289. [CrossRef]

34. Li, J.; Brader, G.; Palva, E.T. Kunitz Trypsin Inhibitor: An Antagonist of Cell Death Triggered by Phytopathogens and Fumonisin B1 in Arabidopsis. Mol. Plant 2008, 1, 482-495. [CrossRef]

35. Lam, E.; Kato, N.; Lawton, M. Programmed cell death, mitochondria and the plant hypersensitive response. Nature 2001, 411, 848. [CrossRef]

36. Miller, G.; Shulaev, V.; Mittler, R. Reactive oxygen signaling and abiotic stress. Physiol. Plant. 2008, 133, 481-489. [CrossRef]

37. Sharma, P.; Jha, A.B.; Dubey, R.S.; Pessarakli, M. Reactive Oxygen Species, Oxidative Damage, and Antioxidative Defense Mechanism in Plants under Stressful Conditions. J. Bot. 2012, 2012, 26. [CrossRef]

38. Du, Y.-Y.; Wang, P.-C.; Chen, J.; Song, C.-P. Comprehensive Functional Analysis of the Catalase Gene Family in Arabidopsis thaliana. J. Integr. Plant Biol. 2008, 50, 1318-1326. [CrossRef]

39. Sun, T.; Liu, F.; Wang, W.; Wang, L.; Wang, Z.; Li, J.; Que, Y.; Xu, L.; Su, Y. The Role of Sugarcane Catalase Gene ScCAT2 in the Defense Response to Pathogen Challenge and Adversity Stress. Int. J. Mol. Sci. 2018, 19, 2686. [CrossRef]

40. Staiger, D.; Korneli, C.; Lummer, M.; Navarro, L. Emerging role for RNA-based regulation in plant immunity. New Phytol. 2013, 197, 394-404. [CrossRef]

41. Li, D.; Zhang, H.; Liu, H.; Wang, X.; Song, F. OsBIRH1, a DEAD-box RNA helicase with functions in modulating defence responses against pathogen infection and oxidative stress. J. Exp. Bot. 2008, 59, 2133-2146. [CrossRef]

42. Restrepo, S.; Myers, K.L.; del Pozo, O.; Martin, G.B.; Hart, A.L.; Buell, C.R.; Fry, W.E.; Smart, C.D. Gene Profiling of a Compatible Interaction Between Phytophthora infestans and Solanum tuberosum Suggests a Role for Carbonic Anhydrase. Mol. Plant-Microbe Interact. 2005, 18, 913-922. [CrossRef]

43. Lukasik, E.; Takken, F.L.W. STANDing strong, resistance proteins instigators of plant defence. Curr. Opin. Plant Biol. 2009, 12, 427-436. [CrossRef]

44. Real, M.D.; Company, P.; García-Agustín, P.; Bennett, A.B.; González-Bosch, C. Characterization of tomato endo- $\beta-1,4$-glucanase Cel1 protein in fruit during ripening and after fungal infection. Planta 2004, 220, 80-86. [CrossRef]

45. Flors, V.; Leyva, M.d.1.O.; Vicedo, B.; Finiti, I.; Real, M.D.; García-Agustín, P.; Bennett, A.B.; González-Bosch, C. Absence of the endo- $\beta$-1,4-glucanases Cel1 and Cel2 reduces susceptibility to Botrytis cinerea in tomato. Plant J. 2007, 52, 1027-1040. [CrossRef]

46. ZEIER, J. New insights into the regulation of plant immunity by amino acid metabolic pathways. Plant Cell Environ. 2013, 36, 2085-2103. [CrossRef]

47. Serrano, I.; Buscaill, P.; Audran, C.; Pouzet, C.; Jauneau, A.; Rivas, S. A non canonical subtilase attenuates the transcriptional activation of defence responses in Arabidopsis thaliana. eLife 2016, 5, e19755. [CrossRef] 
48. Mahadevan, C.; Krishnan, A.; Saraswathy, G.G.; Surendran, A.; Jaleel, A.; Sakuntala, M. Transcriptome- Assisted Label-Free Quantitative Proteomics Analysis Reveals Novel Insights into Piper nigrum-Phytophthora capsici Phytopathosystem. Front. Plant Sci. 2016, 7. [CrossRef]

49. Alban, C.; Tardif, M.; Mininno, M.; Brugière, S.; Gilgen, A.; Ma, S.; Mazzoleni, M.; Gigarel, O.; Martin-Laffon, J.; Ferro, M.; et al. Uncovering the Protein Lysine and Arginine Methylation Network in Arabidopsis Chloroplasts. PLoS ONE 2014, 9, e95512. [CrossRef]

50. Issakidis-Bourguet, E.; Shen, Y.; Zhou, D.-X. Perspectives on the interactions between metabolism, redox, and epigenetics in plants. J. Exp. Bot. 2016, 67, 5291-5300. [CrossRef]

51. Locasale, J.W. Serine, glycine and one-carbon units: Cancer metabolism in full circle. Nat. Rev. Cancer 2013, 13, 572. [CrossRef]

52. Zhang, H.; Deng, X.; Miki, D.; Cutler, S.; La, H.; Hou, Y.-J.; Oh, J.; Zhu, J.-K. Sulfamethazine Suppresses Epigenetic Silencing in Arabidopsis by Impairing Folate Synthesis. Plant Cell 2012, 24, 1230. [CrossRef] [PubMed]

53. Rojas, C.; Senthil-Kumar, M.; Tzin, V.; Mysore, K. Regulation of primary plant metabolism during plant-pathogen interactions and its contribution to plant defense. Front. Plant Sci. 2014, 5. [CrossRef] [PubMed]

54. Abreha, K.B.; Alexandersson, E.; Vossen, J.H.; Anderson, P.; Andreasson, E. Inoculation of Transgenic Resistant Potato by Phytophthora infestans Affects Host Plant Choice of a Generalist Moth. PLoS ONE 2015, 10, e0129815. [CrossRef] [PubMed]

55. Lenman, M.; Ali, A.; Mühlenbock, P.; Carlson-Nilsson, U.; Liljeroth, E.; Champouret, N.; Vleeshouwers, V.G.A.A.; Andreasson, E. Effector-driven marker development and cloning of resistance genes against Phytophthora infestans in potato breeding clone SW93-1015. Theor. Appl. Genet. 2016, 129, 105-115. [CrossRef] [PubMed]

56. Van Der Vossen, E.; Sikkema, A.; Hekkert, B.t.L.; Gros, J.; Stevens, P.; Muskens, M.; Wouters, D.; Pereira, A.; Stiekema, W.; Allefs, S. An ancient R gene from the wild potato species Solanum bulbocastanum confers broad-spectrum resistance to Phytophthora infestans in cultivated potato and tomato. Plant J. 2003, 36, 867-882. [CrossRef] [PubMed]

57. Du, J.; Rietman, H.; Vleeshouwers, V.G.A.A. Agroinfiltration and PVX agroinfection in potato and Nicotiana benthamiana. J. Vis. Exp. JoVE 2014, e50971. [CrossRef] [PubMed]

58. Kessner, D.; Agus, D.; Chambers, M.; Mallick, P.; Burke, R. ProteoWizard: Open source software for rapid proteomics tools development. Bioinformatics 2008, 24, 2534-2536. [CrossRef]

59. The Potato Genome Sequencing, C.; Xu, X.; Pan, S.; Cheng, S.; Zhang, B.; Mu, D.; Ni, P.; Zhang, G.; Yang, S.; Li, R.; et al. Genome sequence and analysis of the tuber crop potato. Nature 2011, 475, 189. [CrossRef]

60. Elias, J.E.; Gygi, S.P. Target-decoy search strategy for increased confidence in large-scale protein identifications by mass spectrometry. Nat. Methods 2007, 4, 207. [CrossRef]

61. Häkkinen, J.; Vincic, G.; Månsson, O.; Wårell, K.; Levander, F. The Proteios Software Environment: An Extensible Multiuser Platform for Management and Analysis of Proteomics Data. J. Proteome Res. 2009, 8 , 3037-3043. [CrossRef]

62. Käll, L.; Storey, J.D.; MacCoss, M.J.; Noble, W.S. Assigning Significance to Peptides Identified by Tandem Mass Spectrometry Using Decoy Databases. J. Proteome Res. 2008, 7, 29-34. [CrossRef] [PubMed]

63. Sandin, M.; Krogh, M.; Hansson, K.; Levander, F. Generic workflow for quality assessment of quantitative label-free LC-MS analysis. Proteomics 2011, 11, 1114-1124. [CrossRef] [PubMed]

64. Teleman, J.; Chawade, A.; Sandin, M.; Levander, F.; Malmström, J. Dinosaur: A Refined Open-Source Peptide MS Feature Detector. J. Proteome Res. 2016, 15, 2143-2151. [CrossRef] [PubMed]

65. Sandin, M.; Ali, A.; Hansson, K.; Månsson, O.; Andreasson, E.; Resjö, S.; Levander, F. An Adaptive Alignment Algorithm for Quality-controlled Label-free LC-MS. Mol. Cell. Proteom. 2013, 12, 1407. [CrossRef] [PubMed]

66. Smyth, G.K. Limma: Linear Models for Microarray Data. Bioinform. Comput. Biol. Solut. Using R Bioconductor 2005, 397-420.

67. Chawade, A.; Alexandersson, E.; Levander, F. Normalyzer: A Tool for Rapid Evaluation of Normalization Methods for Omics Data Sets. J. Proteome Res. 2014, 13, 3114-3120. [CrossRef] [PubMed]

68. Taverner, T.; Karpievitch, Y.V.; Polpitiya, A.D.; Brown, J.N.; Dabney, A.R.; Anderson, G.A.; Smith, R.D. DanteR: An extensible R-based tool for quantitative analysis of -omics data. Bioinformatics 2012, 28, 2404-2406. [CrossRef] [PubMed] 
69. Savitski, M.M.; Lemeer, S.; Boesche, M.; Lang, M.; Mathieson, T.; Bantscheff, M.; Kuster, B. Confident Phosphorylation Site Localization Using the Mascot Delta Score. Mol. Amp. Cell. Proteom. 2011, 10, M110.003830. [CrossRef] [PubMed]

70. Pfaffl, M.W. A new mathematical model for relative quantification in real-time RT-PCR. Nucleic Acids Res. 2001, 29, e45. [CrossRef] [PubMed]

71. Rozen, S.; Skaletsky, H. Primer3 on the WWW for General Users and for Biologist Programmers. Bioinform. Methods Protoc. 2000, 365-386.

72. Chawade, A.; Alexandersson, E.; Bengtsson, T.; Andreasson, E.; Levander, F. Targeted Proteomics Approach for Precision Plant Breeding. J. Proteome Res. 2016, 15, 638-646. [CrossRef] [PubMed]

73. Ghislain, M.; Byarugaba, A.A.; Magembe, E.; Njoroge, A.; Rivera, C.; Román, M.L.; Tovar, J.C.; Gamboa, S.; Forbes, G.A.; Kreuze, J.F.; et al. Stacking three late blight resistance genes from wild species directly into African highland potato varieties confers complete field resistance to local blight races. Plant Biotechnol. J. 2019, 17, 1119-1129. [CrossRef] [PubMed]

(C) 2019 by the authors. Licensee MDPI, Basel, Switzerland. This article is an open access article distributed under the terms and conditions of the Creative Commons Attribution (CC BY) license (http://creativecommons.org/licenses/by/4.0/). 